\title{
ACUTE ORAL TOXICITY ASSESSMENT OF THE ETHANOL EXTRACT OF HOLOTHURIA ATRA IN MICE
}

\section{PANDU SALIM HANAFI $^{1 *}$, AJI SUTRISNO ${ }^{1}$, TUTIK MURNIASIH $^{2}$, HARIJONO$^{1}$, MASTERIA YUNOVILSA PUTRA $^{2}$, FEBRIANA UNTARI ${ }^{2}$}

${ }^{1}$ Department of Agricultural Product Technology, Faculty of Agricultural Technology, Brawijaya University, Malang 65145, Indonesia. ${ }^{2}$ Research Center for Oceanography, Indonesian Institute of Sciences, Jakarta 14430, Indonesia. Email: pandusalimh@student.ub.ac.id

Received: 09 November 2019, Revised and Accepted: 27 December 2019

ABSTRACT

Objective: This study aimed to evaluate the toxicological potential of the ethanol extract of Holothuria atra through the acute oral toxicity - acute toxic class method.

Methods: The sample was immersed in ethanol for $72 \mathrm{~h}$ at room temperature and repeated 3 times. The extracts were evaporated using a vacuum rotary evaporator. The identification of compounds in the ethanol extract of $H$. atra was carried out using liquid chromatography-mass spectrometry (LCMS) analysis. The acute toxicity test was examined the effects of treating male mice with the ethanol extract of $H$. atra at 300 and $2000 \mathrm{mg} / \mathrm{kg}$ by oral administration for 14 days. On the past day of the toxicity test, liver of all experimental animals was taken for histopathological testing.

Results: LCMS analysis showed that the ethanol extract of $H$. atra is contained polar compounds (chlorogenic acid, coumaric acid, a glycosaminoglycan, and holothurin) and non-polar compounds (fatty acids). Acute toxicity study was performed at a dose of 300 and $2000 \mathrm{mg} / \mathrm{kg}$ for 14 consecutive days. No deaths or behavioral changes were observed during the administration of both doses. Histopathological test results on the liver showed a few changes at doses of $2000 \mathrm{mg} / \mathrm{kg}$.

Conclusions: The $\mathrm{LD}_{50}$ is equal to $5000 \mathrm{mg} / \mathrm{kg}$ and the ethanol extracts of $H$. atra can be classified as practically nontoxic. However, further studies are required to proceed to clinical studies in humans.

Keywords: Holothuria atra, Ethanol extract, Safety dose, Acute toxicity, $\mathrm{LD}_{50}$

(C) 2020 The Authors. Published by Innovare Academic Sciences Pvt Ltd. This is an open access article under the CC BY license (http://creativecommons. org/licenses/by/4. 0/) DOI: http://dx.doi.org/10.22159/ajpcr.2020.v13i2.36316

\section{INTRODUCTION}

Holothuria atra is one of the species of sea cucumbers from the family Holothuriidae and it is found worldwide [1]. H. atra is one type of sea cucumber that is relatively inexpensive but rarely consumed due to the presence of saponin compounds that make it taste bitter [2]

H. atra contains a variety of bioactive compounds such as glycoside, lectin, steroidal sapogenin, saponins, triterpenoids, phenols, and alkaloids [3,4]. The previous studies report that $H$. atra has pharmacological activities, including antioxidants [5,6], antibacterial [7], anti-inflammatory [3], and immunomodulatory effects [1,8].

A previous study proved that sea cucumbers (Holothuria) also contain a toxic compound called holothurin [9]. H. atra is reported to contain saponins (triterpene glycosides) types of holothurin A, holothurin A2, holothurin B, holothurin B1, and holothurin B2 [10,11]. Therefore, we need a toxicity test for the ethanol extract of sea cucumber $H$. atra so that the lethal median dose $\left(\mathrm{LD}_{50}\right.$; the amount of an ingested substance that kills $50 \%$ of a test sample) value is known.

\section{MATERIALS AND METHODS}

\section{Sample preparation}

Samples of $H$. atra collected from the Mutun Pesawaran Beach, Lampung, Indonesia. The animals were immediately washed under running tap water and cut open, and all visceral organs were removed. The animals were rinsed thoroughly of any internal organs or body fluids and dried at $40-50^{\circ} \mathrm{C}$. Then, the dried body walls of the animals were transported to our laboratory in an icebox with dry ice and stored at $-20^{\circ} \mathrm{C}$ until processing [5].

\section{Extraction method}

The extraction method is a modification of the previous work [6]. The sample weighed $500 \mathrm{~g}$ and cut into pieces $\left(2-3 \mathrm{~cm}^{2}\right)$ and then immersed in ethanol (proAnalyst, MERCK; 1:5; w/v) for $72 \mathrm{~h}$ at room temperature and stirring occasionally. The process was repeated 3 times until the filtrate obtained was clear. The filtrate obtained was then filtered using Whatman No.1 filter paper and then evaporated using a rotary vacuum evaporator (IKA RV 10 Basic; $40^{\circ} \mathrm{C}, 90 \mathrm{rpm}$ ) with Minichiller 300 Huber. Then, the supernatant residue is stored at $-20^{\circ} \mathrm{C}$.

Liquid chromatography-mass spectrometry (LCMS) analysis Chromatographic methods refer to the previous research [12]. Chromatography was performed on a Water Alliance high-performance liquid chromatography 2695 (Waters Associates Inc., Milford, MA, USA) connected to a Water 3100 quadrupole mass spectrometer through an electrospray ionization interface, consisting of an autosampler, a column heater-cooler, a quaternary pump, and a nitrogen gas generator unit (NM30LA-MS Gas Generator from Peak Scientific Instruments Ltd., MA, USA).

Chromatographic separation was carried out on a Symmetry C18 analytical column $(50 \times 2.1 \mathrm{~mm}, 3.5 \mathrm{~mm}$ particle size, Waters $)$. Mobile phases consisting of water (Solvent A) and $\mathrm{MeOH}$ (Solvent B) both with $0.1 \mathrm{mM} \mathrm{NH}_{4} \mathrm{Ac}$ and $0.01 \% \mathrm{HCOOH}$ at different ration and flow rate were tested. The flow rate was $300 \mu \mathrm{L} / \mathrm{min}$. The sample injection volume was $20 \mu \mathrm{L}$. All data were acquired and processed using MassLynx version 4.1 (Waters).

\section{Ethical consideration}

Experimental protocols and procedures used in this study were approved by the Brawijaya University, Bioscience Institute, Research 
Ethics Committees (Indonesia) (1018-KEP-UB). All the experimental procedures were carried out in accordance with international guidelines for the care and use of laboratory animals.

\section{Toxicity study}

The acute toxicity test was conducted according to the Organization for Economic Cooperation and Development (OECD) Guidebook 423. The acute oral toxicity - acute toxic class method was applied in the present study to determine the median lethal dose $\left(\mathrm{LD}_{50}\right)$ [13]. The male mice used in the $\mathrm{LD}_{50}$ test were $\mathrm{BALB} / \mathrm{c}$ strains aged 6-7 w with a body weight of 18-20 g. Animals must adapt to the new environment for 7 days before the study and given standard food and drink ad libitum. Three experimental animals used at each step. Starting dose or initial dose to start can be selected from four fixed doses of 5, 50,300, and $2000 \mathrm{mg} / \mathrm{kg} \mathrm{BW}$. Since there is no relevant information on the ethanol extract of $H$. atra that can cause death, the toxicity test will start at a dose of $300 \mathrm{mg} / \mathrm{kg}[14]$

After adjusting to the environment, experimental animals were divided into two groups with three male mice in each group. The first group is the control group, and the second group is the ethanol extract group. The animals in the experimental groups were administered to samples (dissolved in distilled water), and the control group was treated with distilled water. All animals must be fasted before experimentation (but drinking water may be given). Each mouse was marked before the experiment and the initial body weight (fasting for $4 \mathrm{~h}$ ) was recorded. An ethanol extract of $H$. atra is given in a single dose (onetime administration). The gavage was performed with a volume of $10 \mathrm{ml} / \mathrm{kg}$ [15]. Observations were made at $30 \mathrm{~min}, 1 \mathrm{~h}, 2 \mathrm{~h}$, and $4 \mathrm{~h}$ (given specifically for the first $4 \mathrm{~h}$ ) after the sample administration, and then, feed with known weight was offered. Further observations were done once a day for 14 days. The test is not continued at the next dose until it is known whether the animal is still alive or dead (OECD, 2001). Meanwhile, the mortality (if any) and abnormity (signs of toxicity) of mice were also recorded $[14,16]$

\section{Histopathological analysis}

A small portion of the liver tissue of each mouse was fixed in 10\% formalin, processed, and embedded in paraffin wax to obtain $5 \mu \mathrm{m}$ thick slices using a microtome. Hematoxylin and eosin stain was applied to the sections. Then, they were examined under a light inverted microscope. Staining was needed to observe the color, shape, and size of hepatocytes. Hematoxylin stained the nucleus blue. Eosin stained the cytoplasm red [17]

\section{Statistical analysis}

Data were expressed as mean \pm standard deviation. Body weight data of the different groups were determined by analysis of variance (one-way analysis of variance) followed by the Tukey post hoc test. $\mathrm{p}<0.05$ was considered statistically significant.

\section{RESULTS}

\section{LCMS analysis}

The yield of $H$. atra extraction using ethanol was $8.54 \mathrm{~g}(1.71 \%)$. The LCMS analysis revealed that ethanol extract of $H$. atra contains various types of bioactive compounds (Table 1 ).

The ethanol extract of H. atra is known to contain polar compounds such as phenolic (Chlorogenic acid and coumaric acid), glycosaminoglycan, and saponins (holothurin) to non-polar compounds such as fatty acids.

\section{Acute toxicity study}

Single doses of $300 \mathrm{mg} / \mathrm{kg}$ body weight of the ethanol extract of $H$. atra given to mice during the acute toxicity study did not cause any death or changes in the parameters evaluated when compared to the control group. Then, the dose of ethanol extract was increased at $2000 \mathrm{mg} / \mathrm{kg} \mathrm{BB}$ also caused no death and no clinical signs of toxicity in any of the treated animals (Table 2). The exposed mice showed no changes in physiological habits during the treatment period.
All animals survived test substance administration gained body weight, appeared active and healthy during the study. There were no signs of gross toxicity, adverse pharmacologic effects, or abnormal behavior. The acute oral lethal dose $\left(\mathrm{LD}_{50}\right)$ of the ethanol extract of $H$. atra in mice has been estimated to be $5000 \mathrm{mg} / \mathrm{kg}$.

\section{Behavioral sign of toxicity}

Mortality is a clear sign of toxicity, but other variables may indicate more subtle adverse effects such as weight loss during the treatment and clinical signs of toxicity [18]. Observations to display signs of toxicity include changes in skin and fur, diarrhea, tremors, convulsions, and mortality [14].

The group mean values of body weights of the mice treated with 300 and $2000 \mathrm{mg} / \mathrm{kg}$ body weight of the ethanol extract of $H$. atra did not differ significantly from those of the control groups during the study (Fig. 1). No alterations or adverse effects in growth were observed in animals in any of the dosing groups.

\section{Histopathological analysis}

Histological test results of hematoxylin and eosin staining in the liver or liver of mice showed that the liver in mice extract a group of $2000 \mathrm{mg} / \mathrm{kg}$ body weight was damaged compared to extract group $300 \mathrm{mg} / \mathrm{kg}$ body

Table 1: Chemical composition of the ethanol extract of Holothuria atra

\begin{tabular}{lll}
\hline No. & Nama Senyawa & Berat Molekul (g/mol) \\
\hline 1. & Chlorogenic acid & 354,31 \\
2. & Squalene & 410,7 \\
3. & Glycine & 75,13 \\
4. & Glutamic acid & 147,13 \\
5. & Coumaric acid & 164,16 \\
6. & Arginine & 174,2 \\
7. & Palmitoleic acid (C16:1) & 254,41 \\
8. & Palmitic acid (C16:0) & 256,43 \\
9. & Lanosterol & 426,7 \\
10. & Chondroitin sulfate & 463,37 \\
11. & Heparan sulfate & 637,5 \\
12. & Linoleic acid (C18:2) & 280,4 \\
13. & Oleic acid (C18:1) & 282,5 \\
14. & Stearic acid (C18:0) & 284,5 \\
15. & Sulfated glycosaminoglycan & 301,27 \\
16. & Eicosapentaenoic acid (C20:5) & 302,5 \\
17. & Arachidonic acid (C20:4) & 304,5 \\
18. & Glutathione & 307,33 \\
19. & Arachidic acid (C20:0) & 312,5 \\
20. & Docosahexaenoic acid (C22:6) & 328,5 \\
21. & Panaxoside A/Ginsenoside RG1 & 801 \\
22. & Holothurin B3 & 866 \\
23. & Holothurin B1 & 868 \\
24. & Holothurin B/B4 & 882 \\
25. & Holothurin B2 & 884 \\
26. & Holothurin A & 1221,3 \\
\hline
\end{tabular}

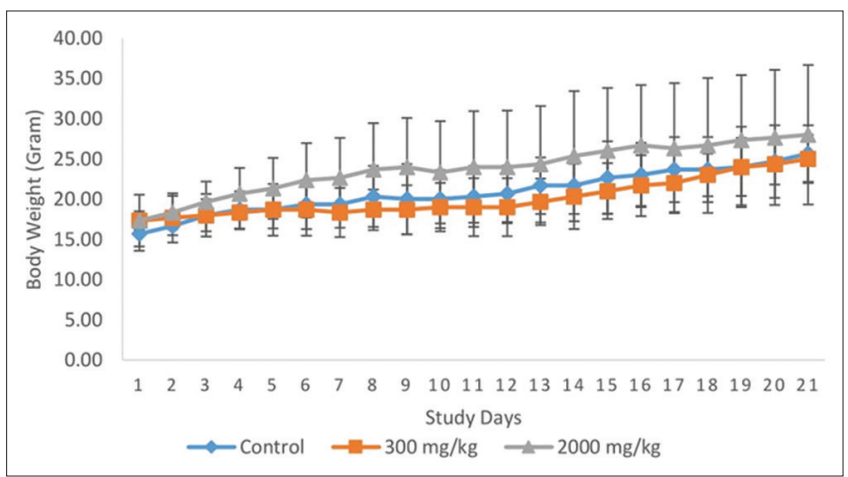

Fig. 1: Body weights of animals 


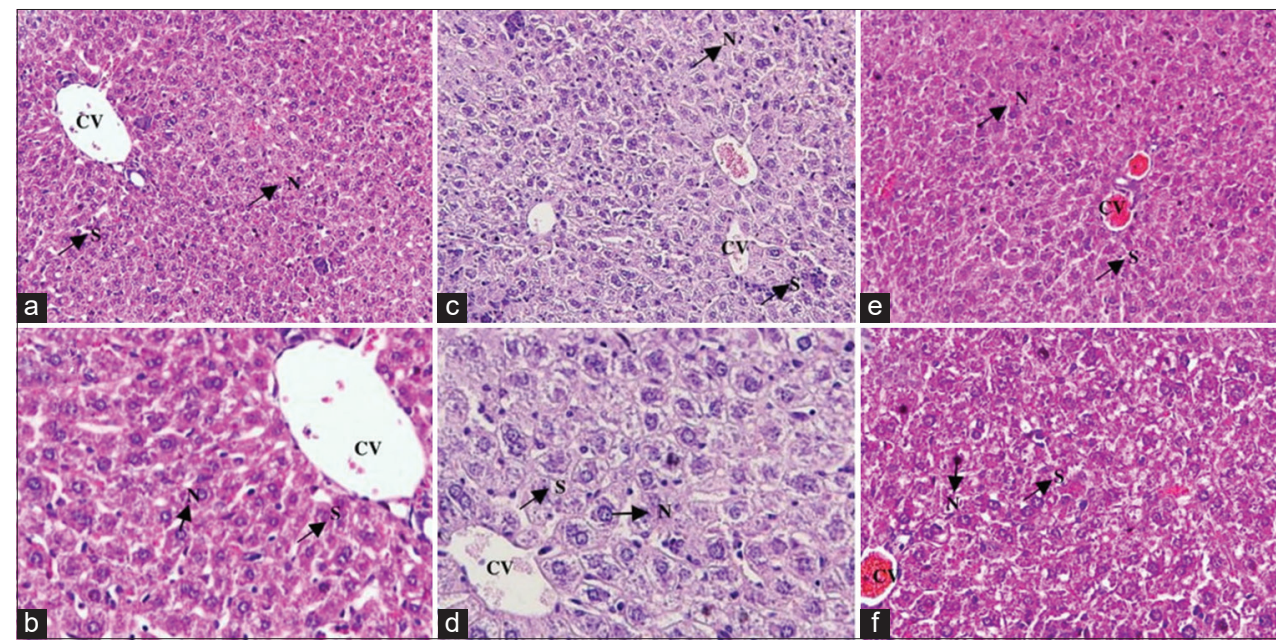

Fig. 2: Histopathological results of livers in mice after oral administration in the acute toxicity ( $\mathrm{H}$ and $\mathrm{E}$ : $200 \times$ and $400 \times)$, control (a and b); $300 \mathrm{mg} / \mathrm{kg}$ ethanol extract (c and d); $2000 \mathrm{mg} / \mathrm{kg}$ ethanol extract ( $\mathrm{e}$ and $\mathrm{f}$ ), $\mathrm{N}=$ nucleus; $\mathrm{CV}=$ central vein; $\mathrm{S}=$ sinusoid

weight and negative control. This can be seen on the arrows in the picture, which shows that many nucleus cells are damaged or called pyknosis. Observations in the $300 \mathrm{mg} / \mathrm{kg} \mathrm{BW}$ extract group, the cell nucleus was seen to be unchanged compared with the negative control group. This shows that the extract group of $300 \mathrm{mg} / \mathrm{kg}$ body weight and control did not occur in the histological structure of the liver of male mice.

\section{DISCUSSION}

The study examined the effects of treating male mice for 14 days with 300 and $2000 \mathrm{mg} / \mathrm{kg}$ of body weight of the ethanol extract of $H$. atra by oral administration. Both doses of ethanol extract of $H$. atra did neither cause death and no any obvious toxicity symptom in all mice. Observation of signs of toxicity is carried out individually every $30 \mathrm{~min}$ in the first $4 \mathrm{~h}$ after administration of the test preparation, and periodically every $4 \mathrm{~h}$ for the first $24 \mathrm{~h}$ and once a day after that for 14 days. Observations made include the condition of the skin and hair, eyes, convulsions (convulsions), tremors (shaking), diarrhea, and death [14]. The previous study was also reported that phosphate-buffered saline extracts of H. atra which was given orally at a dose $2000 \mathrm{mg} / \mathrm{kg}$ did not show any signs of toxicity or cause death in mice [5].

The ethanol extract of $H$. atra was used in the acute toxicity test by oral administration that did not show any signs of toxicity or cause death in experimental animals up to a dose of $2000 \mathrm{mg} / \mathrm{kg}$ so that the globally harmonized system is classified as category five or unclassified. Therefore, according to the method of acute toxicity classification [19], it can deduce that the $\mathrm{LD}_{50}$ values of ethanol extract of $H$. atra are equal to $5000 \mathrm{mg} / \mathrm{kg}$ and regarded as practically nontoxic.

Body weight is summarized in Fig. 1. As shown in Fig. 1, the weight of mice was an increase from day 1 to day 21 in all groups. It was found that there were significant differences in the average body weight of mice each day in each group $(\mathrm{p}<0.05)$. Qualitative testing results show that the ethanol extract of $H$. atra contains steroids, which has an effect on metabolic activity so that it can increase appetite [20].

Liver damage can be caused by many exogenous drugs and other chemical substances by a variety of mechanisms, including cellular degeneration and necrosis by interfering directly with various specific biochemical reactions [21]. The liver is the first organ to encounter ingested nutrients, vitamins, metals, and drugs. The liver functions to detoxify toxic substances so that liver damage is an indication of whether a substance is toxic or not.

In this study, control liver tissue indicated the presence of normal hepatocytes which are polyhedral in shape with defined cell lining;
Table 2: Behavioral signs of toxicity effects of the ethanol extract of $H$. atra administered (oral) to mice

\begin{tabular}{lll}
\hline $\begin{array}{l}\text { Dose of } \boldsymbol{H} \text {. atra } \\
\text { extract }(\mathbf{m g} / \mathbf{k g})\end{array}$ & $\begin{array}{l}\text { Observed } \\
\text { mortality }(\mathrm{D} / \mathrm{T})\end{array}$ & $\begin{array}{l}\text { Toxic } \\
\text { symptoms }\end{array}$ \\
\hline 0 & $0 / 3$ & None \\
300 & $0 / 3$ & None \\
2000 & $0 / 3$ & None \\
\hline
\end{tabular}

$0 \mathrm{mg} / \mathrm{kg}=$ control group that was given distilled water through oral; D/T: Dead/ treated mice; None: No toxic symptoms were seen during the observation period. H. atra: Holothuria atra

nuclei are distinctly rounded, with one or two prominent nucleoli [17]. The liver section at doses of $2000 \mathrm{mg} / \mathrm{kg}$ indicated the presence of abnormal hepatocytes with an enlarged nucleus (Fig. 2). Damage to the liver is characterized by cell necrosis or changes in the nucleus [21]. The chromatin of the cell clumps into coarse and the nucleus will be shrink, dense, and dark blue when colored by hematoxylin. This process is called pyknosis. The pyknotic nucleus can then be broken down into many small basophilic particles (karyorrhexis) or will be lysis as a result of the action of lysosomal deoxyribonuclease (karyolysis). Pyknosis can be interpreted as the nucleus of cells that have shriveled up, so it looks smaller than normal size, and generally, cells that have pyknosis will look dark in color [17].

Congestion is a term that indicates the excess blood volume in a part of a blood vessel. This can occur because too much blood gets into the arteries or too little goes to the veins. Microscopically congestion can be characterized by dilatation in the artery or capillary wall caused by the large volume of blood in that area [22]. The damage to the central vein can be caused by too much blood being collected, this can cause the accumulation of toxic substances so that the damage becomes even more obvious [23].

The results of the study show that the ethanol extract of $H$. atra detected to contains holothurin A, holothurin B/B4, holothurin B1, holothurin B2, and holothurin B3 (Table 1). Holothurin is a type of saponin that exists in sea cucumbers and generally exists in the form of triterpene glycosides [24]. $H$. atra was reported to contain saponins (triterpene glycosides) of holothurin A, holothurin A2, holothurin B, holothurin B1, and holothurin B2 [10]. The previous studies have shown that holothurin isolated from Holothuria vagabunda can have hemolytic effects (damage red blood cells) and hyperemia (increase blood flow to body tissues) which it happens for a long time can cause permanent changes in tissue (atrophy, necrosis, and hypoxia) [9]. The sea cucumber toxin extract can increase the level of hematocrit, hemoglobin, red blood 
cells, and white blood cells after 120 min injected intraperitoneally in mice [25]. Holothurin is hygroscopic and soluble in water at unlimited rate. At room temperature it solves in ethanol containing water, but it does not dissolve in ethanol with a concentration of more than $94 \%$ as well as in other organic solvents. It's very foamy by stirred, resistant to heat (not decomposed at $100^{\circ} \mathrm{C}$ ), and also have a strong hemolytic effect. The effects of holothurin can be reduced by cholesterol in the blood and hydrolyzed by acids (peptic acid) during the digestive process [9].

The five parameters of the sign of toxicity in the acute toxicity did not show behavioral changes or cause death. It is important to measure the acute clinical signs in an attempt to establish a lethal dose that can cause the death of $50 \%$ of the animals tested $\left(\mathrm{LD}_{50}\right)$ to obtain parameters for further clinical trials of toxicity, specifically subacute, subchronic, and chronic toxicity $[26,27]$. In this study, therefore, it is assumed that the $\mathrm{LD}_{50}$ is equal to $5000 \mathrm{mg} / \mathrm{kg}$.

\section{CONCLUSIONS}

In the present work, the acute toxicity of the ethanol extract of $H$. atra in mice was performed. The result of acute toxicity showed that oral single administration of 300 and $2000 \mathrm{mg} / \mathrm{kg}$ of the extract did not cause mortality or sudden death. Therefore, the $\mathrm{LD}_{50}$ of extract for male mice was equal to $5000 \mathrm{mg} / \mathrm{kg}$ and regarded as practically nontoxic. However, the ethanol extract of H. atra is exhibited toxicities to heart in mice determined by histopathological analysis when treated by oral administration of high doses $(2000 \mathrm{mg} / \mathrm{kg})$.

\section{ACKNOWLEDGMENT}

The authors are grateful to Research Center for Oceanography, Indonesian Institute of Sciences, for providing the research facilities and financial support to this research.

\section{AUTHORS' CONTRIBUTION}

Febriana Untari and Masteria Yunovilsa Putra contributed to the collection of the sample and performed the extraction; Pandu Salim Hanafi contributed to the preparation of the manuscript and carried out the experiments; Aji Sutrisno and Tutik Murniasih has supervised the experimental process; Harijono contributed to article proofreading and revision of the article. The final manuscript was approved by all the authors.

\section{CONFLICTS OF INTEREST}

The study was conducted at Marine Natural Product Laboratory, Research Center for Oceanography, Indonesian Institute of Sciences, Jakarta and Food Nutrition Laboratory, Department of Agricultural Product Technology, Faculty of Agricultural Technology, Brawijaya University, Malang, Indonesia. Tutik Murniasih is an employee of the Research Center for Oceanography, Indonesian Institute of Sciences, Jakarta, Indonesia.

\section{REFERENCES}

1. Saad DY, Baiomy AA, Mansour AA. Antiseptic effect of sea cucumber (Holothuria atra) against multi-organ failure induced by sepsis: Molecular and histopathological study. Exp Ther Med 2016;12:222-30.

2. Van Dyck S, Caulier G, Todesco M, Gerbaux P, Fournier I, Wisztorski M, et al. The triterpenoid glycosides of Holothuria forskali, usefulness and efficiency as a chemical defense mechanism against predatory fish. J Exp Biol 2011;214:1347-56.

3. Bordbar S, Anwar F, Nzamid S. High value components and bioactives from sea cucumbers for functional foods. A review. J Mar Drugs 2011;9:1761-805.

4. Murniasih T, Putra MY, Pangestuti R. Antioxidant capacities of
Holothuria sea cucumbers. Ann Bogorienses 2015;19:21-6.

5. Dakrory AI, Fahmy SR, Soliman AM, Mohamed AS, Amer SA. Protective and curative effects of the sea cucumber (Holothuria atra) extract against DMBA induced hepatorenal diseases in rats. BioMed Res Int 2015;2015;563-652.

6. Pangestuti R, Murniasih T, Putra MY, Rasyid A, Wibowo JT, Ardiansyah A, et al. Free radical scavenging activity of selected sea cucumber species from Mataram-Lombok, Indonesia. J Teknol Sci Eng 2016;78:179-85.

7. Dhinakaran DI, Lipton AP. Bioactive compounds from Holothuria atra of Indian Ocean. Springerplus 2014a;3:673.

8. Dhinakaran DI, Lipton AP. Pharmacological potentials of sea cucumber Holothuria atra extracts from the Indian Ocean. Asian J Biomed Pharm Sci 2014b;4:36-43.

9. Yamanouchi T. On the poisonous substance contained in holothurians. Publ Seto Mar Biol Lab 1995;4:183-203.

10. Dyck SV, Gerbaux P, Patrick F. Qualitative and quantitative saponin contents in five sea cucumbers from the Indian Ocean. Mar Drugs 2010;8:173-89.

11. Kalinin VI, Avilov SA, Silchenko AS, Stonik VA. Triterpene glycosides of sea cucumbers (Holothuroidea, Echinodermata) as taxonomic markers. Nat Prod Commun 2015;10:21-6.

12. Salman M, El-Sayed S, Hameed A, Bazaid SA, Al-Shamranib MG, Mohamed HF. Liquid Chromatography-Mass Spectrometry (LC-MS) method for the determination of sugars in fresh pomegranate fruit juices. Pharm Chem 2014;6:320-33.

13. Belhekar SN, Chaudhari PD. Acute and sub-acute oral toxicity assessment of the polyherbal formulation in albino Wister rats. Int $\mathrm{J}$ Pharm Pharm Sci 2016;8:311-16.

14. Organization for Economic Cooperation and Development. Test Guideline 423 : Acute Oral Toxicity Acute Toxic Class Method. Paris, France: Organization for Economic Cooperation and Development; 2001. p. 1-14

15. Ajput MA, Zehra T, Ali F, Kumar G. Assessment of analgesic activity of Nelumbo nucifera fruit ethanol extract. Int $\mathrm{J}$ Pharm Pharm Sci 2019;11:1-5

16. Xiang F, Peng L, Yin Z, Jia R, Hu Z, Li Z, et al. Acute and subchronic toxicity as well as evaluation of safety pharmacology of Galla chinensis solution. J Ethnopharmacol 2015;162:181-90.

17. Hashim R, Azizan NA, Zamli Z, Zulkipli FH, Mazlan N, Althunibat OY. Toxicity effects of water extracts of Holothuria atra jaeger in mice. Asian Pac J Trop Biomed 2014;4:614-7.

18. Traesel GK, de Souza JC, de Barros AL, Souza MA, Schmitz WO, Muzzi RM, et al. Acute and subacute (28 Days) oral toxicity assessment of the oil extracted from Acrocomia aculeata Pulp in rats. Food Chem Toxicol 2014;74:320-5.

19. Duan WL, Liang XM. Technical Guidelines Assembly of Veterinary Medicine Research. Beijing: Chemical Industry Press; 2011.

20. Huberman A. Shrimp endocrinology: A review. Aquaculture 2000;191:191-208

21. Chandrasoma P, Taylor CR. Concise Pathology. $3^{\text {rd }}$ ed. Singapore: McGraw-Hill; 1997.

22. Jones TC, Hunt RD, King NW. Veterinary Pathology. $6^{\text {th }}$ ed. USA: Lippincott Williams and Wilkins; 1997.

23. Price SA, Wilson LM. Patofisiologi: Konsep Klinis Proses-Proses Penyakit. ${ }^{\text {th }}$ ed., Vol. 4. Jakarta: EGC; 1995.

24. Bahrami Y, Franco CM. Acetylated triterpene glycosides and their biological activity from Holothuroidea reported in the past six decades. Mar Drugs 2016:14:147.

25. Zaki MA. Effects of the crude toxin of sea cucumbers Holothuria atra on some hematological and biochemical parameters in rats. Egypt J Nat Toxins 2005;2:71-86.

26. Organization for Economic Cooperation and Development. Guidelines for Testing of Chemical. Acute Oral Toxicity up and Down Procedure. Paris: Organization for Economic Cooperation and Development; 2008.

27. de Lima FF, Traesel GK, Menegati SE, Santos AC, Souza RI, de Oliveira VS, et al. Acute and subacute oral toxicity assessment of the oil extracted from Attalea phalerata Mart Ex Spreng. pulp fruit in rats. Food Res Int 2017;91:11-7. 